\title{
Nilai-Nilai Tradisi Peusijuek Sebagai Pembelajaran Sejarah Berbasis Kearifan Lokal
}

\author{
Okhaifi Prasetyo $^{1}$, Dyah Kumalasari ${ }^{2}$ \\ ${ }^{1}$ Mahasiswa Magister Pendidikan Sejarah, Fakultas Ilmu Sosial, Universitas Negeri Yogyakarta, Jl. Colombo \\ Yogyakarta No.1, Karang Malang, Caturtunggal, Kec. Depok, Kabupaten Sleman, \\ Daerah Istimewa Yogyakarta 55281, Indonesia \\ ${ }^{2}$ Fakultas Ilmu Sosial, Universitas Negeri Yogyakarta, Jl. Colombo Yogyakarta No.1, Karang Malang, \\ Caturtunggal, Kec. Depok, Kabupaten Sleman, Daerah Istimewa Yogyakarta 55281, Indonesia
}

Iokhaifiprasetyo.2019@student.uny.ac.id

Pembelajaran sejarah mengintegrasikan beberapa unsur nyata yang terdapat di lingkungan untuk mencapai sebuah tujuan. Unsur tersebut bisa didapatkan melalui sebuah kearifan lokal yang ada pada masyarakat. Tujuan penulisan ini yaitu mengetahui nilai-nilai yang ada dalam Tradisi Peusijuek sebagai pembelajaran sejarah berbasis kearifan lokal. Menggunakan metode deskripsi kualitatif dengan teknik pengumpulan data kepustakaan, observasi dan dokumentasi. Data yang terkumpul kemudian dianalisis menggunakan teknik analisis data yaitu reduksi data, penyajian data, dan penarikan kesimpulan. Hasil menunjukkan bahwa Kearifan lokal merupakan gagasan setempat yang bersifat bijaksana, penuh kearifan, bernilai baik, yang tertanam dan diikuti oleh anggota masyarakat. Hal ini selaras dengan masyarakat Aceh yang percaya, bahwa tradisi Peusijuek merupakan hasil kearifan lokal yang diajarkan nenek moyang mengenai budaya dan agama yang harus dijalankan secara berdampingan dengan segala kebaikan yang ada di dalamnya. Sehingga, dapat disimpulkan bahwa nilai-nilai yang muncul pada tradisi Peusijeuk sebagai pembelajaran sejarah yaitu meliputi nilai toleransi, nilai religius, nilai sosial dan nilai kerjasama.

Kata kunci: kearifan lokal; peusijuek; sejarah

\section{The Values of Peusijuek Tradition as Historical Studies Based On Lokal Wisdom}

Historical study integrates some elements in society to achieve objectives. These elements can be obtained through lokal wisdom that lies in certain society. This study aimed to know the values within Peusijuek tradition as historical studies based on the lokal wisdom. The methodology used was descriptive qualitative with observation and documentation as the data collection techniques. The collected data were analyzed using data reduction, data serving, and drawing conclusion. The results indicated that lokal wisdom is a lokal idea that is wise, full of wisdom, good value, which is embedded and followed by community members. This is in accordance with the society of Aceh who believe that Peusijeuk tradition is a result of lokal wisdom taught by the ancestors on culture and religion that must be carried out along with the goodness inside. Thus, it can be concluded that the values that appeared in Peusijeuk tradition as a historical studies, including tolerance, religion, social and teamwork.

Keywords: lokal wisdom; peusijuek; historical

Proses Review : 1 - 30 Juni 2021, Dinyatakan Lolos: 27 Juli 2021 


\section{PENDAHULUAN}

Pendidikan memiliki peran yang sangat penting dalam mencedaskan kehidupan bangsa dan pembentukan sikap nasionalisme terhadap negara. Di era modern, pendidikan merupakan suatu kebutuhan yang tidak bisa lepas dari kehidupan manusia dan dapat dijadikan sebagai modal yang harus dimiliki dalam menghadapi tuntutan zaman. Untuk itu perlu adanya usaha dalam meningkatkan kualitas pendidikan. Peningkatan kualitas pendidikan dapat dilihat dari keberhasilan belajar peserta didik dalam mencapai tujuan utama pembelajaran tersebut. Peningkatan kualitas pendidikan yang baik akan membentuk bangsa yang kuat dan loyal terhadap negara, salah satu cara yang dapat dilakukan yaitu melalui pembelajaran sejarah agar mereka memiliki rasa nasionalisme yang tinggi.

Kartodirjo (1992) proses national building for national identitiy yang dilakukan republik ini, menuntut rekonstruksi sejarah sebagai sejarah nasional yang akan mewujudkan kristalisasi identitas bangsa Indonesia. Rekonstruksi nilai sejarah secara menyeluruh dan lengkap bagi warga masyarakat salah satunya dapat dilakukan di lembaga penyelenggara pendidikan, yakni dengan pembelajar an sejarah secara berkelanjutan di sekolah-sekolah. Mata pelajaran sejarah mengajarkan kepada siswa untuk memahami bagaimana bangsanya dibangun sehingga bangsa Indonesia sampai seperti sekarang. Pembelajaran sejarah memang dapat dipergunakan untuk melatih warga negara yang setia karena memang kisah tanah airnya dapat menimbulkan rasa bangga pada diri kaum patriot atau jika kisah itu dapat demikian diubah dan disesuaikan sehingga nampaknya lebih mulia.

Pembelajaran sejarah juga dapat integrasikan dalam beberapa unsur yang dapat memperkuat tujuan utama, seperti mengaitkan dengan hal-hal nyata yang ada di lingkungan sekitar. Menurut Jumardi (2017) pembelajaran sejarah juga dapat di integrasikan kedalam budaya lokal setempat. Budaya merupakan suatu kebiasaan atau prilaku masyarakat di daerah tertentu, budaya juga merupakan suatu proses yang dinamis serta memiliki nilai-nilai dan norma-norma kehidupan yang berlaku dalam tata cara pergaulan masyarakat tertentu. Dari budaya tersebut maka terciptalah ragam kebiasaan masyarakat, di antaranya bahasa daerah, kesenian tari, musik, dan upacara adat, semua ini adalah hasil dari bagian budaya. Pentingnya mengaitkan budaya dalam pembelajaran merupakan salah satu cara untuk melestarikan kearifan lokal dan proses pengenalan terhadap peserta didik. Hal ini dapat dilakukan, agar budaya lokal mampu menumbuhkan jiwa nasionalisme.

Jika ditinjau dari manfaat pembelajaran sejarah menurut Umamah et al. (2017), yaitu memberikan pengetahuan tentang bangsa, sikap sebagai bangsa, dan kemampuan penting untuk mengembangkan kehidupan pribadi peserta didik, masyarakat dan bangsa. Pembeajaran sejarah juga memiliki manfaat menumbuhkan pemahaman peserta didik terhadap diri sendiri, masyarakat, dan proses terbentuknya bangsa Indonesia. Untuk itu, guru mata pelajaran sejarah diberikan kesempatan untuk mengembangkan materi sesuai dengan yang ada di sekitar peserta didik, seperti memilih materi untuk mengangkat budaya daerah setempat yang mengandung kerifan lokal.

Kearifan lokal diartikan sebagai gagasan setempat yang bersifat bijaksana, penuh kearifan, serta bernilai baik dalam masyarakat, yang tertanam dan diikuti oleh anggota masyarakat seterusnya. Kearifan lokal dipengaruhi oleh kebudayaan dari masing-masing daerah dan Indonesia merupakan salah satu negara yang mempunyai banyak sekali kearifan lokal yang khas di setiap daerahnya. Melihat fenomena ini, maka kreativitas guru dalam memasukkan kebudayaan lokal menjadi suatuderf pembelajaran sejarah merupakan salah satu usaha untuk mengembangkan pendidikan berbasis kearifan lokal. Maka, penulisan ini akan mengangkat salah satu budaya lokal yang ada di Indonesia yaitu tradisi Peusijuek yang berasal dari Provinsi Aceh dan akan dikaji nilai-nilainya untuk pembelajaran sejarah. Tradisi Peusijuek dalam penelitian yang dilakukan oleh Sakina et al. (2018) yang berjudul pesijuek sebagai media dakwah di Aceh, yaitu suatu amalan yang secara turun temurun dan tidak mungkin terhapus, bahkan senantiasa mengiringi setiap upcara atau, apakah sosio-budaya, sosio-kemasyarakatan maupun sosio-keagamaan.

Berdasarkan uraian tersebut maka penulis tertarik untuk menulis mengenai apa saja nilai-nilai tradisi Peusijuek sebagai pembelajaran sejarah berbasis kearifan lokal.

\section{METODE PENELITIAN}

Metode yaitu tuntutan tentang bagaimana secara berurut penelitian dilakukan, menggunakan alat dan bahan apa, prosedurnya (Widi 2010). Penelitian menggunakan pendekatan kualitatif, untuk memahami fenomena tentang apa yang dialami oleh subjek penelitian, misalnya prilaku, persepsi, tindakan, dan lain-lain secara holistik dan dengan cara deskripsi dalam bentuk kata-kata dan bahasa pada suatu konteks khusus yang alamiah dan dengan memanfaatkan berbagai metode alamiah (Moleong 2017). Alasan penggunaan metode ini yaitu ada beberapa petimbangan di antaranya adalah penulis ingin menggambarkan, menguraikan suatu hal sesuai dengan apa yang ada pada tradidi Peusijeuk, dengan maksud menggunakan data yang dikumpulkan, berupa fakta di lapangan dan kata-kata atau penalaran.

Teknik pengumpulan data dilakukan melalui: (1) Studi Kepustakaan, yang merupakan suatu proses pencarian literatur dan sumber bacaan yang nantinya dapat memperlancar proses penelitian. Kegiatan ini merupakan 
teknik untuk melengkapi kekurangan-kekurangan data sekaligus sebagai media untuk melengkapi dan menganalisa data yang diperoleh dalam penelitian lapangan. Selain sumber bacaan berupa buku, makalah, jurnal, buletin, artikel, penulis juga berusaha mencari referensi lain dari internet. (2) Dokumentasi, agar penulis lebih mudah memperoleh data yang diperlukan dalam waktu singkat, karena biasanya data ini sudah tersusun dan tersimpan dengan baik berupa buku-buku atau literatur, arsip atau foto dan mampu menggambarkan suatu fenomena tertentu. (3) Observasi, tepatnya Observasi partisipan yang merupakan pengumpulan data untuk menghimpun data penelitian melalui pengamatan dan pengindraan, di mana observer atau peneliti benar-benar terlibat dalam keseharian responden. Hal ini dilakukan untuk mengetahui secara langsung tradisi Peusijeuk yang ada di dalam masyarakat Aceh.

Teknik analisis data yang digunakan dalam penelitian ini adalah mengacu pada konsep Miles dan Huberman (1992), yaitu interactive model yang mengklasifikasikan analisis data dalam 3 langkah: (1) Reduksi Data (Data Reduction), yaitu suatu proses pemilahan, pemusatan perhatian pada penyederhanaan, pengabstrakan dan transformasi data kasar yang muncul dari catatan-catatan tertulis di lapangan. Reduksi data yang dilakukan yaitu memilih data agar terfokus pada tujuan dan kesesuain tema. (2) Penyajian Data (Display Data), tersusun sedemikian rupa sehingga memberikan kemungkinan adanya penarikan kesimpulan dan pengambilan tindakan. (3) Penarikan Kesimpulan (Verification), akan diungkap mengenai makna dari data yang dikumpulkan. Verifikasi dilakukan dengan melihat kembali reduksi data maupun penyajian data sehingga kesimpulan yang diambil tidak menyimpang, dan mencari hubungan antara sumber yang satu dengan yang lain, menjadi satu kesatuan.

\section{ANALISIS DAN INTEPRETASI DATA}

Tradisi Peusijuek dalam masyarakat Aceh telah menjadi suatu kebiasaan yang berawal dari amalan yang turuntemurun dan tidak mungkin terhapus, bahkan senantiasa mengiringi setiap upacara kemasyarakatan, keagamaan dan lainnya. Noviana (2018), menyatakan bahwa tradisi peusijuk belum bisa diketahui kebenarannya. Tradisi tersebut adalah peninggalan budaya Hindu yang masih dianut oleh umat Islam, khususnya masyarakat Aceh. Walaupun ada beberapa orang menganggap tradisi peusijuk ini hampir mirip dengan tradisi agama Hindu, namun dalam segi cara, isi dan tujuannya sangat berbeda. Masyarakat Aceh percaya, bahwa tradisi Peusijuek ini merupakan hasil kearifan budaya lokal yang diajarkan nenek moyang, karena budaya dan agama harus dijalankan secara berdampingan dengan segala kebaikan yang ada di dalamnya. Sehingga harus dihormati dan dijaga keberadaannya. Prosesi Peusijuek sudah menjadi budaya yang terus dipertahankan, Peusijuek mengandung nilai- nilai agama yang sangat filosofis sehingga Peusijuek dianggap sangat sakral dan mesti dilakukan pada kegiatankegiatan yang diyakini perlu adanya Peusijuek. Bahkan sampai kepada yang sangat ekstrim, Peusijuek dianggap amalan agama yang tidak boleh ditinggalkan. Hal tersebut menunjukkan, bahwa proses seseorang menerima budaya yang datang dan dikembangkan dalam suatu masyarakat (lokal process) tidak memakan waktu yang sebentar dan semerta-merta. Menurut Hariadi et al. (2020) secara bahasa, tradisi Peusijuek mengandung dua pegertian, yaitu (1) adat kebiasaan turun temurun (dari nenek moyang) yang masih dijalankan di masyarakat, (2) penilaian atau anggapan bahwa cara-cara yang telah ada merupakan yang paling baik dan benar. Sedangkan Peusijuek menurut Riezal et al. (2019), secara bahasa berasal dari akar kata sijeuk yang ditambah awalan peu berarti menjadikan sesuatu agar dingin atau mendinginkan.

Snouck (1985), menjelaskan sebelum suatu kegiatan dimulai harus dilakukan upaya-upaya untukmenghindarkan pengaruh-pengaruh jahat dan diterapkan pula cara-cara untuk memastikan yang secara teknis disebut "penyejuk". Sebagaimana diketahui dalam bahasa-bahasa daerah di nusantara kebahagiaan, kedamaian, ketentraman dan kesejateraan semua tergabung dalam konsep "sejuk", sedangkan kata "panas" mewakili segala macam kekuatan jahat. Oleh sebab itu bila seseorang menghalau kekuatan "panas" atau cukup mujur membebaskan diri dari serangan itu adat menggariskan cara penyejuk untuk memantapkan kesejahteraan diri yang telah ditemukanya kembali atau berhasil diselamatkan dari ancaman. Cara yang sama juga digunakan untuk menghalau kekuatan-kekuatan jaat yang dianggap mutlak perlu dienyahkan. Misalnya selesai dibangun rumah baruu dan berbagai pesta keluarga lainya dijadikan ajang proses "penyejukan". Di Aceh penyejukan disebut Peusijeuk. Sehingga dalam Tradisi Peusejeuk terkandung kearifan lokal.

Ratih and Suryana (2020), mengemukakan bahwa kearifan lokal mengacu pada berbagai kekayaan budaya yang tumbuh dan berkembang yang berlandas nalar jernih, budi yang baik, dan memuat hal poitif yang berada didalam kehidupan masyarakat. Quaritch Wales merumuskan kearifan lokal atau lokal genius sebagai "the sum of the cultural characteristic which the vast majority of a people have in common as a result of their experiences in early life". Pokok pikiran yang terkandung dalam definisi tersebut adalah (1) karakter budaya, (2) kelompok pemilik budaya, serta (3) pengalaman hidup yang lahir dari karakter budaya.

Pingge (2017), juga menambahkan bahwasanya kearifan lokal bertujuan untuk tata nilai sosial, ekonomi, peningkatan kesejahteraan dan menciptakan kedamaian. Kearifan lokal digali dari produk kultural yang menyangkut hidup dan kehidupan komunitas pemiliknya, misalnya sistem nilai, kepercayaan dan agama, etos kerja, bahkan 
bagaimana dinamika itu berlangsung (Kusuma 2018). Kearifan lokal memiliki signifikasi serta fungsi sebagai berikut : (1) Identitas suatu daerah; (2) Sebagai Pemersatu masyarakat; (3) Sebagai warisan budaya yang diterima dan diaplikasikan; (4) Sebagai kekayaan budaya suatu komunitas; (5) Sebagai pola pikir dan karakter dalam berinteraksi sosial dengan mengutamakan kepentingan umum; (6) Sebagai perekat kebersamaan dalam menjaga kelestarian identitas dari ancaman dan pengaruh dari luar serta mendorong terbangunnya kebersamaan, apresiasi sekaligus sebagai sebuah mekanisme bersama untuk menepis berbagai kemungkinan yang meredusir bahkan merusak solidaritas komunal yang dipercaya dan disadari tumbuh di atas kesadaran bersama dari sebuah komunitas terintegrasi.

\section{Nilai-nilai Kearifan Lokal Tradisi Peusejeuk dalam Pembelajaran Sejarah}

Melalui budaya dan hal nyata yang ada disekitar hidup maka diharapkan dengan akan mengingatkan pengalamanpengalaman yang dialami secara baik, dan pengalaman tersebut adalah cara menanamamkan nilai-nilai kearifan lokal. Hidayat (2015) menyatakan proses komunikasi lintas budaya dalam tradisi Peusijuek pada masyarakat gampong indrapuri terjadi melalui proses akulturasi atau percampuran unsur-unsur budaya hindu dan unsurunsur budaya islam. unsur-unsur budaya hindu yang terdapat pada tradisi Peusijuek adalah memercikkan air, menaburkan beras, dan sesajian. unsur-unsur budaya islam yang terdapat pada tradisi Peusijuek adalah doa, silahturahmi, bersyukur, dan sedekah. Akulturasi hindu dan islam dalam tradisi Peusijuek tersebut terjadi karena adanya motivasi dan keterbukaan masyarakat dalam mengubah tradisi Peusijuek. Tradisi Peusijuek bukan hanya sebagai bentuk tradisi ritual saja tetapi juga sebagai bentuk komunikasi masyarakat dalam menjalin hubungan yang lebih baik.

Pada tradisi Peusijeuk terdapat beberapa nilai-nilai kearifan lokal. Menurut Wibowo (2013), nilai tersebut dimakna dari penyelenggaraan Peusijuek adalah: (1) Talam mengandung makna bahwa orang yang diPeusijuek tetap bersatu dalam lingkungan keluarga yang ditinggalkan. (2) Clok (calok) mengandung makna bahwa orang yang di Peusijuek itu tetap berada dalam lingkungan keluarga yang di lingkungan keluarga (persatuan) dan berhemat. (3) Tudung saji (sangee) mengandung makna diharapkan untuk mendapatkan perlindungan dari Allah swt. dari segala tipu daya yang menyesatkan. (4) Beras padi mengandung makna bahwa orang diPeusijuek semakin tua semakin berilmu, juga merupakan makan pokok atau benih untuk menghasilkan. (5) Tepung tawar mengandung makna bahwa tepung berwarna putih merupakan perlambang kebersihan dan kesejukan jiwa bagi orang yang di Peusijuek. (6) On manek-mano mengandung makna bahwa sesuai dengan deretan bunga diharapkan digalang persatuan dan kesatuan serta keteraturan. (7) $\mathrm{On}$ sijuek mengandung makna obat penawar atau kesejukan meresap kalbu. (8) Naleung Samboe mengandung makna dengan sifatnya yang kokoh sulit untuk dicabut, pelambang sebagai kekokohan pendirian dan etika, baik dalam kehidupan bermasyarakat maupun agama. (9) $\mathrm{Bu}$ leukat mengandung makna zat perekat, pelambang sebagai daya tarik untuk tetap meresap dalam hati orang yang diPeusijuek semua ajaran dan nasihat ke jalan yang diridhai oleh Allah swt.

Dalam bukunya identitas Aceh dalam perspektif syariat dan adat Ali (2013) mengemukakan bahwa makna dari tahaptahap yang digunakan dalam Peusijuek adalah pertama setelah membaca basmallah kemudian kedua menaburkan beras dan padi, sifat padi itu semakin berisi semakin merunduk, maka diharapkan bagi yang di Peusijuek supaya tidak sombong bila mendapat keberhasilan serta mengharap agar mendapatkan kesuburan, kemakmuran, dan semangat seperti taburan beras padi yang begitu semarak berjatuhan. Kemudian ketiga menyuapi nasi ketan (bu leukat) dan menyuntingnya pada telinga sebelah kanan, dipilih nasi ketan karena mengandung zat perekat, sehingga jiwa raga yang di Peusijuek tetap berada dalam lingkungan keluarga atau kelompok masyarakatnya. Lalu yang terakhir adalah pemberian uang (teumutuep) secara filosofi teumeutuep memiliki makna sedekah, sedangkan sedekah salah satu pilar dalam mencapai kemakmuran dalam masyarakat.

Penyelenggaraan Peusijeuk tersebut dapat dilihat banyaknya nilai yang terkandung dalam setiap tahapan maupun filosofi dari bahan yang digunakann. Mahardika (2017), mengemukakan bentuk-bentuk kearifan lokal dalam masyarakat dapat berupa nilai, norma, etika, kepercayaan, adat-istiadat, dan aturan-aturan khusus. Nilai-nilai yang ada dalam kearifan lokal, memunculkan nilai etika, nilai estetika, nilai religius, dan nilai sosial.

Berbicara masalah kearifan lokal dalam penulisan ini lebih diarahkan pada nilai-nilai yang melekat dalam ragam budaya di suatu tempat dalam konteks khususnya yaitu Tradisi Peusijeuk. Nilai-nilai itu sendiri seringkali tidak ditulis atau tersurat, tetapi diakui keberadaannya oleh masyarakat sekitar dan menjadikan sebuah keharusan. Pengertian nilai-nilai sering dirumuskan dalam konsep yang berbeda-beda. Saminan (2013), menyatakan bahwa nilai adalah patokan normatif yang mempengaruhi manusia dalam menentukan pilihannya di antara caracara bertindak dalam aktivaitas. Hal ini memiliki tekanan utama pada nilai budaya tempatan sebagai faktor eksternal yang selalu mempengaruhi sifat dan karakter manusia itu sendiri seperti adab dan nilai seni. Tabiat manusia sebagai salah satu bagian terpenting dari kehidupan sosial sebab dengan penegakkan moral atau etika, siswa dapat merasa tenang dan terbebas dari segala konspirasi masyarakat yang akan merugikan dirinya. Nilai inilah yang muncul sebagai pembelajaran sejarah. 
Sirnayatin (2017), berpendapat bahwa pembelajaran sejarah merupakan cabang ilmu pengetahuan yang menelaah tentang asal-usul dan perkembangan serta penanan maasyarakat pada masa lampau yang mengandung nilai-nilai kearifan yang dapat digunakan untuk melatih kecerdasan membentuk sikap, watak dan kepribadian peserta didik (Depdiknas 2003). Pembelajaran sejarah berfungsi untuk menyadarkan peserta didikakan adanya proses perubahan dan perkembangan masyarakat dalam dimensi waktu dan untuk membangun perspektif serta kesadaran sejarah dalam menemukan, memahami, dan menjelaskan jati diri bangsa dimasa lalu, masa kini, dan masa depan ditengah-tengah perubahan dunia. Sedangkan menurut Kusnoto dan Minandar (2017), pembelajaran sejarah juga merupakan cara untuk membangkitkan rasa nasionalisme pemuda terhadap bangsa serta membentuk sikap sosial. Adapun sikap sosial tersebut antara lain: saling menghormati, menghargai perbedaan, toleransi dan kesediaan untuk hidup berdampingan dalam nuansa multikulturalisme Berdasarkan hal tersebut maka melalui pembelajaran sejarah dapat sangat strategis untuk membentuk nilai yang baik. Beberapa nilai yang terkandung dalam tradisi Peusijeuk antara lain nilai toleransi, nilai religi, nilai kerjasama, dan nilai sosial.

Nilai toleransi Peusijuek merupakan salah satu contoh asimilasi Islam dan budaya lokal di Indonesia. Peusijuek merupakan produk budaya atau Islam budaya yang bagi sebagian masyarakat telah menganggap dan menjadikannya bagian dari Islam. Pelaksanaan Peusijuek dilakukan sesuai dengan kesepakatan antara beberapa pihak anatar pelaku dan penyelenggara Peusijeuk tersebut.

Riezal et al. (2019), menyatakan bahwa dalam budaya masyarakat Aceh, tradisi Peusijuek pada dasarnya dapat berfungsi untuk memohon keselamatan, ketentraman, dan kebahagiaan dalam kehidupan. Meski demikian, fungsi dari tradisi Peusijeuk juga dapat dibagi ke dalam beberapa jenis, yang diantaranya seperti, Peusijuek Meulangga (yaitu perselisihan atau konflik), Peusijuek Padee Bijeh (yaitu saat mulai menanam padi), Peusijuek Tempat Tinggai (yaitu menghuni rumah), Peusijuek Peudong Rumoh Baro (yaitu membangun rumah baru), Peusijuek Keurubeuen (yaitu saat hari berkurban), Peusijuek kendaraan, Peusijuek kitan, PeusijuekHaji, dan Peusijuek Pernikahan. Jika dilihat dari prosesi pelaksanaannya, memang banyak sekali dilakukan, namun hal ini tidak harus dilaksanakan dalam keadaan ketidakmampuan dimana masyarakat memberikan pandangan bahwasanya tidak adanya sanksi sosial yang diterima.

Nilai Religi terdapat dalam tradisi Peusijeuk tersebut mencirikan dua kebudayaan, yaitu hasil dari masa hindu budha dengan islam, dimana pada prosesinya menggunakan banyak makanan yang pada masa hindu budha salah satunya adalah syarat sesaji dan diadopsi pada masa islam untuk sedekah makanan. Namun pada pelaksanaannya selalu diawali dengan doa dan nilainilai religius. Dalam prosesi Peusijuek biasanya yang menguasai doa-doa ini adalah pelaku Peusijuek inti, yaitu Tengku (ustadz). Kemudian orang-orang yang ikut peuijuek berikutnya hanya membaca surah al-fatihah atau doa-doa keselamatan dalam bahasa Aceh. Doa-doa yang dibacakan pada saat Peusijuek merupakan doa-doa keselamatan, baik dalam Bahasa Arab maupun berbahasa Aceh. Doa-doa biasanya disesuaikan dengan momen dari Peusijuek. Doa-doa tersebut meminta keselamatan, kedamaian dan kemudahan rizki dari Allah.

Peusijuek diyakini dan beroperasi menjadi sebuah kepercayaan masyarakat yang secara keagamaan hal tersebut bukan sepenuhnya murni berasal dari ajaran agama. Hal ini menandakan pentingnya interaksi antar manusia dan Tuhannya. Melalui hal tersebut dapat di integrasikan kedalam pembelajaran sejarah bahwasanya sebelum memulai sesuatu di harus awali dengan doa.

Berkaitan dengan kepercayaan masyarakat Aceh mengenai Prosesi Peusijuek yang sudah menjadi budaya yang terus dipertahankan, Peusijuek mengandung nilai-nilai agama yang sangat filosofis sehingga Peusijuek dianggap sangat sakral dan wajib dilakukan pada kegiatan-kegiatan yang diyakini perlu adanya Peusijuek. Bahkan sampai kepada yang sangat ekstrim, Peusijuek dianggap amalan agama yang tidak boleh ditinggalkan dan tidak dapat dipisahkan dari kehidupan umat beragama islam. Bila meninggalkannya akan ditimpa musibah atau tidak ada keberkatan dalam menjalankan kegiatan sehari-harinya. Kepercayaan masyarakat Aceh dalam mempertahankan Peusijuek merupakan salah satu keyakinan bahwa sesuatu itu dianggap benar dan nyata serta suatu sikap yang ditunjukkan oleh seorang maupun kelompok terhadap sesuatu berdasarkan pengetahuan yang dimilikinya dan di yakini bahwa hal tersebut telah mencapai taraf kebenaran sesuai dengan agama yang dianutnya.

Nilai Kerjasama yang diperoleh dari tradisi Peusijuek yaitu masyarakatan mengenal adanya unsur kegotongroyongan dalam kegiatanya tersebut yang tercermin dari hal masak-memasak oleh para tetangga sekitar dan saling bantu membantu menyukseskan acara. Tujuan diadakannya tradisi Peusijuek ini juga untuk membangun silaturahmi dengan kerabat maupun keluarga. Saat prosesi Peusijuek digelar, keluarga dan warga sekitar biasanya turut diundang.

Nilai sosial berkaitan dengan perhatian dan perlakukan terhadap sesama manusia. Nilai ini tercipta karena manusia sebagai makhluk sosial. Manusia harus menjaga hubungan antara sesamanya, hubungan inilah yang akan menciptakan sebuah keharmonisan dan sikap saling membantu berdasarkan kesadaran individu masingmasing. Nilai sosial yang yang tercermin misalnya salah satu kesempatan berkumpulnya angota keluarga, kerabat, 
dan warga setempat adalah dalam sebuah acara Peusijeuk. berkumpulnya masyrakat yang terdiri dari berbagai lapisan sosial menandakan bahwa diantara mereka terjalinnya rasa sosial diantara yang tinggi sepeti saling menghormati dan menghargai serta melakukan sedekah terhadap sesama.

\section{SIMPULAN}

Tradisi Peusijuek merupakan hasil kearifan budaya lokal yang diajarkan nenek moyang. Dimana budaya dan agama harus dijalankan secara berdampingan dengan segala kebaikan yang ada di dalamnya. Sehingga harus hormati dan dijaga keberadaannya. Peusijuek juga mengandung nilai-nilai agama yang sangat filosofis sehingga dianggap sakral dan wajib dilakukan. Bahkan dianggap salah satu amalan agama yang tidak boleh ditinggalkan. Nilai-nilai kearifan lokal yang terdapat pada Tradisi Peusijeuk sebagai pembelajaran sejarah yaitu mencakup nilai toleransi, nilai religius, nilai sosial, dan nilai kerjasama.

\section{DAFTAR RUJUKAN}

Ali, F. 2013. Identitas Aceh Dalam Perspektif Syariat Dan Adat. Banda Aceh: Badan Arsip Perpustakaan Aceh.

Depdiknas. 2003. Kurikulum 2004: Standar Kompetensi Mata Pelajaran Sains Sekolah Menengah Pertama Dan Madrasah Tsanawiyah. Jakarta: Depdiknas.

Hariadi, Joko, Muhammad Arif Fadhillah, and Azrul Rizki. 2020. "Makna Tradisi Peusijeuk Dan Peranannya Dalam Pola Komunikasi Lintas Budaya Masyarakat Di Kota Langsa." JURNAL SIMBOLIKA: Research and Learning in Communication Study 6 (2): 121-33. https:// doi.org/10.31289/simbollika.v6i2.3993.

Hidayat, Rahmat. 2015. Komunikasi Lintas Budaya Dalam Tradisi Peusijuek Pada Masyarakat Gampong Indrapuri, Kecamatan Indrapuri, Aceh Besar. Aceh.

Jumardi, Jumardi. 2017. "Peranan Pelajaran Sejarah Dalam Pengembangan Karakter Siswa Melalui Pembelajaran Berbasis Nilai Sejarah Lokal Di SMA Negeri 65 Jakarta Barat." Jurnal Pendidikan Sejarah 6 (2): 70. https://doi. org/10.21009/JPS.062.08.

Kartodirjo, Sartono. 1992. Pendekatan Ilmu Sosial Dalam Metodologi Sejarah. Jakarta: PT Gramedia.

Kusnoto, Yuver, and Fandri Minandar. 2017. "Pembelajaran Sejarah Lokal Pemahaman Kontens Bagi Mahasiswa." Jurnal Pendidikan Sosial 4 (1): 125-37. https://doi.org/ http://dx.doi.org/10.31571/sosial.v4i1.428.

Kusuma, Rendra Sakbana. 2018. "Peran Sentral Kearifan Lokal Dalam Peningkatan Kualitas Pendidikan.” Jurnal Pedagogik 5 (2): 228-39. https://doi.org/https://doi. org/10.33650/pjp.v5i2.385.
Mahardika, Alhafizh. 2017. "Penanaman Karakter Bangsa Berbasis Kearifan Lokasi Di Sekolah." Jurnal Pendidikan Kewarganegaraan 7 (2): 16-27.

Miles, Matthew B, and A. M Huberman. 1992. Analisis Data Kualitatif. Edited by Tjetjep Rohendi Rohidi. Jakarta: Universitas Indonesia Press.

Moleong, Lexy J. 2017. "Metodologi Penelitian Kualitatif (Edisi Revisi).” In PT. Remaja Rosda Karya.

Noviana, Nana. 2018. "Integritas Kearifan Lokal Budaya Masyarakat Aceh Dalam Tradisi Peusijuk Aceh." DESKOVI: Art and Design Journal 1 (1): 29-34.

Pingge, Delu Herominus. 2017. "Kearifan Lokal Dan Penerapannya Di Sekolah." Jurnal Edukasi Sumba 1 (2): 128-35.

Ratih, Dewi, and Aan Suryana. 2020. "Nilai-Nilai Kearifan Lokal Leuweung Gede Kampung Kuta Ciamis Dalam Mengembangkan Green Bihavior Untuk Meningkatkan Karakter Mahasiswa." Jurnal Artefak 7 (2): 79. https://doi. org/10.25157/ja.v7i2.4199.

Riezal, Chaerol, Hermanu Joebagio, and Susanto Susanto. 2019. "Konstruksi Makna Tradisi Peusijuek Dalam Budaya Aceh." Jurnal Antropologi: Isu-Isu Sosial Budaya 20 (2): 145. https://doi.org/10.25077/jantro.v20.n2.p145155.2018

Sakina, Sakina, Dewa Nyoman Rai Asmara Putra, and I Gusti Ayu Agung Ari Krisnawati. 2018. "Penerapan Penyelesaian Sengketa Dengan Gugatan Sederhana (Small Claim Court) Di Pengadilan Negeri (Studi Kasus Di Pengadilan Negeri Denpasar)." Kertha Wicara 7 (4).

Saminan, Ismail. 2013. Budaya Sekolah Islami. Cetakan Pe. Bandung: Rafki.

Sirnayatin, Titin Ariska. 2017. "Membangun Karakgter Bangsa Melalui Pembelajaran Sejarah." Jurnal SAP 1 (3): 312-21.

Snouck, Hurgronje. 1985. Aceh Di Mata Kolonialis. Jakarta: Yayasan Soko Guru.

Umamah, Nurul, Sumardi Sumardi, and Eni Sri Wahyuni. 2017. "Pengembangan Cerita Sejarah Gayatri Sri Rajapatni Perempuan Pembangun Imperium Majapahit Pada Mata Pelajaran Sejarah SMA." Jurnal Pendidikan Dan Humaniora 55 (1): 63-68.

Wibowo, A.B. 2013. "Peusijuek Dalam Masyarakat Aceh." KEMDIKBUD. 2013. http://kebudayaan.kemdikbud. go.id/bpnbaceh/2013/12/19/Peusijuek-dalam-masyarakataceh/\#respond. 
Widi, Restu Kartiko. 2010. Asas Metodologi Penelitian.

Yogyakarta: Draha Ilmu. 